\title{
KARAKTERISASI RESERVOIR UNTUK MENENTUKAN PERSEBARAN BATUPASIR PEMBAWA HIDROKARBON MENGGUNAKAN INVERSI SIMULTAN
}

\section{RESERVOIR CHARACTERIZATION FOR DETERMINING HYDROCARBON BEARING SANDS DISTRIBUTION USING SIMULTANEOUS INVERSION}

\author{
Juventa $^{\mathbf{l}^{*}}$, Fatkhan $^{2}$ \\ ${ }^{1}$ Program Studi Teknik Geofisika, Universitas Jambi \\ ${ }^{2}$ Program Studi Teknik Geofisika, Institut Teknologi Bandung
}

Received: 2020, August $18^{\text {th }}$

Accepted: 2020, December $7^{\text {th }}$

Keyword:

Simultaneous Inversion;

LMR;

Reservoir.

Corespondent Email:

juventa@unja.ac.id

How to cite this article:

Juventa \& Fatkhan. (2021).

Karakterisasi Reservoir

Untuk Menentukan
Abstrak. Dalam eksploitasi hidrokarbon, salah satu tantangan yang paling penting adalah pemetaan persebaran batuan reservoir dan fluida pengisinya. Salah satu metode yang digunakan adalah inversi simultan. Inversi simultan merupakan salah satu teknik inversi seismik yang mengekstraksi data AVO untuk memperoleh nilai impedansi seismik dari data seismik Pre-Stack hingga memperoleh nilai impedansi P dan S serta densitas. Salah satu metode lanjutan yang paling umum dipakai adalah metode Lambda-Mu-Rho (LMR) untuk membatu identifikasi litologi dan fluida reservoir. Penelitian dilakukan dengan menggunakan data dari Lapangan Nova Scotia, dengan target pada batu-pasir Formasi Missisauga. Data yang digunakan adalah data sumur L-30 dan B-41 dan data seismik 3D PSTM. Sumur B-41 berada di struktur lebih tinggi dari sumur L-30 namun tidak menghasilkan hidrokarbon. Log Vs dibuat sintetik menggunakan metode Fluid Replacement Modeling dan LMR diturunkan dengan transformasi log $V p$, Vs dan densitas. Hasil pemetaan zona target pada kedalaman 2095-2250 ms yaitu dengan menggunakan range cutoff Lambda-Rho 17-22 $\mathrm{Gpa}^{\star} \mathrm{g} / \mathrm{cc}$ dan $\mathrm{Mu}-\mathrm{Rho} 20-28 \mathrm{Gpa}^{*} \mathrm{~g} / \mathrm{cc}$ maka didapat peta persebaran batuan reservoir dan hidrokarbon. Hasil interpretasi dari peta sebaran menunjukkan sumur B-41 adalah dry hole karena lapisan batupasir mempunyai nilai $\mathrm{Mu}$-Rho rendah yang diakibatkan lapisan tipis dan perselingan dengan batulempung.

Abstract. One of the most important challenge in hydrocarbon exploration is mapping the distribution of reservoir properties and its filling fluid. One method that usually is being use for is simultaneous inversion. Simultaneous inversion is 
Persebaran Batupasir Pembawa Hidrokarbon Menggunakan Inversi Simultan. Jurnal Geofisika Eksplorasi, 07(01), 5-16.

(C) 2021 JGE (Jurnal Geofisika Eksplorasi). This article is an open access article distributed under the terms and conditions of the Creative Commons Attribution (CC BY NC) a seismic inversion technique that extracts AVO data to obtain seismic impedance values from the Pre-Stack seismic data such as $P$ and $S$ impedance values and density. One of the most commonly used methods for the next step is the Lambda-Mu-Rho (LMR), to help identify lithology and resorvoir fluid. This research was conducted by using data from the Nova Scotia Field, with the target on the sandstone of the Missisauga Formation. We used well data L-30 and B41 and 3D PSTM seismic data. Well B-41 is on a higher structure than well L30 but does not produce hydrocarbons. Log Vs was made synthetically using the FRM method and the LMR was derived by transforming the log Vp, Vs and Density. By mapping the target zone at a depth of 2095-2250 ms using the cutoff range Lambda-Rho 17-22 Gpa*g/cc and Mu-Rho 20-28 Gpa ${ }^{*}$ /cc, a map of the distribution of reservoir rocks and and its filling hydrocarbons were obtained. The results of the reservoir distribution map show that B-41 well is a dry hole because the sandstone layer has a low Mu-Rho value due to a thin layer and an intersection with claystone.

\section{PENDAHULUAN}

Interpretasi kuantitatif detail suatu reservoir hidrokarbon dapat dijadikan sebagai referensi pengembangan lapangan reservoir dan meningkatkan produksinya, sebagian besar pengembangan lapangan reservoir hidrokarbon ini dilakukan dengan mengintegrasikan data sumur, data seismik dan data geologi (Ekine, 2013). Penentuan dimensi dari reservoir (ketebalan dan luas area penyebaran) menjadi hal yang penting karena akan berkaitan erat dengan nilai ekonomis dari reservoir itu sendiri.

Menurut Veire \& Landro (2006), parameter elastis yang didapat dari data seismik merupakan suatu data yang dapat digunakan untuk mengkarakterisasi sebuah reservoir berdasarkan hubungan empiris antara sifat fisis batuan, fluida pengisi pori dan kecepatan gelombang P. Dengan menambahkan komponen gelombang $\mathrm{S}$ yang tidak bisa merambat melalui fluida, memperkaya informasi tentang litologi batuan serta fluida pengisi porinya.

Hampson dkk., (2005) memperkenalkan pendekatan baru simultaneous pre-stack inversion yang lebih singkat dan terintegrasi dengan memakai tiga asumsi yaitu: perkiraan linear dari nilai reflektivitas dapat digunakan, reflektivitas PP dan PS sebagai fungsi dari sudut menggunakan persamaan Aki-Richards, dan adanya hubungan antara logaritma impedansi $\mathrm{P}$, impedansi $\mathrm{S}$ dan densitas.

Penelitian ini menggunakan data yang disediakan oleh Departemen Energi Nova Scotia, Kanada yaitu pada lapangan offshore Penobscot dengan target reservoir adalah perselingan antara batupasir dan lempung pada formasi Missisauga. Formasi Missisauga yang menjadi zona target pada penelitian ini dibagi menjadi Lower, Middle dan Upper. Lower Missisauga mulai terbentuk pada masa Jurasik akhir yang ditandai dengan adanya pengangkatan dan progradasi delta Sable yang dimulai pada pengendapan formasi MicMac sebelumnya. Lower Missisauga terdiri dari batupasir dan lapisan tipis batugamping dan batu-serpih. Lingkungan pengendapan fluviodeltaic terus berlnjut hingga masa awal Kapur membentuk middle dan upper Missisauga. Antara Lower dan Middle-Upper Missisauga dipisahkan oleh batuan karbonat yang dinamakan "O-marker" (Campbell, 2014).

Formasi Missisauga adalah formasi reservoir utama yang telah terbukti menghasilkan gas (sumur L-30) di lapangan Penobscot, Kanada dengan jenis batuannya adalah batupasir. Sumur B-41 yang dibor setelah sumur L-30 ternyata $d r y$ hole, tidak menghasilkan 
hidrokarbon. Hal ini menjadi ironi karena setelah dilihat data peta struktur waktu, lapisan batupasir zona target pada B-41 terletak pada struktur waktu yang lebih tinggi daripada sumur L-30 (Gambar 1) walaupun litologi batupasir pada sumur B-41 lebih tipis. Hal ini menimbulkan pertanyaan, jika menggunakan konsep structural trap mengapa hidrokarbon terakumulasi di daerah yang relatif lebih rendah. Untuk mencari jawaban tersebut maka penulis mencoba menggunakan pendekatan dari metode inversi simultan data seismik untuk mencari tahu perbedaan karakter reservoir antara kedua lokasi sumur tersebut.

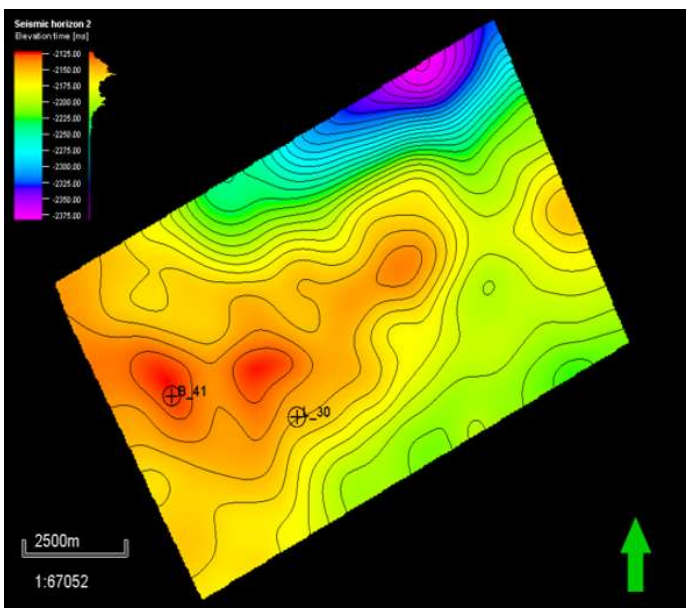

Gambar 1. Peta struktur waktu batas atas zona reservoir batupasir.

\section{TEORI DASAR}

\subsection{Kecepatan Gelombang P}

Log sonik gelombang $\mathrm{P}$ terukur melalui transit time dari waveform antara transmitter dan receiver. Gelombang $\mathrm{P}$ merupakan gelombang yang arah penjalarannya searah dengan arah getarannya. Kecepatan gelombang $\mathrm{P}$ memiliki hubungan dengan sifat fisis batuan yaitu densitas, inkompresibilitas dan rigiditas (Mavko dkk., 1998). Secara matematis hubungan parameter tersebut mengikuti persamaan berikut:

$$
\mathrm{V}_{\mathrm{P}}=\sqrt{\frac{\lambda+2 \mu}{\rho}}
$$

dengan:

$\mathrm{V}_{\mathrm{P}} \quad=$ kecepatan gelombang $\mathrm{P}$

$\lambda=$ inkompresibilitas

$\mu \quad=$ rigiditas

$\rho \quad=$ densitas

\subsection{Kecepatan Gelombang $S$}

Menurut Mavko dkk. (1998) dan Liu (2017) Gelombang $\mathrm{S}$ memiliki arah penjalaran yang orthogonal terhadap arah getarnya atau disebut dengan gelombang transversal. Hubungan kecepatan gelombang $\mathrm{S}$ dengan sifat fisis batuan (Mavko dkk., 1998) ditunjukan oleh persamaan berikut:

$$
\mathrm{V}_{\mathrm{S}}=\sqrt{\frac{\mu}{\rho}}
$$

dengan:

$\mathrm{V}_{\mathrm{S}} \quad=$ kecepatan gelombang $\mathrm{S}$

$\mu \quad=$ rigiditas

$\rho \quad=$ densitas

\section{3. $A V O$}

Metode amplitude versus offset atau yang biasa disebut dengan AVO adalah suatu metode analisis data seismik yang memperhatikan perubahan amplitudo sebagai fungsi dari jarak atau offset. Metode AVO didasarkan pada anomali naiknya amplitudo sinyal seismik terhadap bertambahnya jarak suatu penerima (offset) dan suatu pemantul (reflector). Pada kondisi normal ketika tidak dijumpai adanya anomali, semakin bertambah jarak offset semakin besar pula sudut datangnya dan amplitudonya akan semakin kecil. Namun pada kasus AVO, amplitudo akan semakin besar dengan bertambahnya jarak offset (Castagna \& Swan, 1997). AVO berkembang berdasarkan adanya variasi perubahan koefisien refleksi dan transmisi terhadap sudut datang, yang berkaitan dengan hubungan jarak reflektifitas. 


\subsection{Inversi Simultan}

Inversi seismik adalah teknik pemodelan geologi bawah permukaan menggunakan data seismik sebagai masukan data dan data sumur sebagai kontrol (Sukmono, 2007). Inversi simultan merupakan salah satu teknik inversi AVO yang melibatkan data seimik pre-stack. Inversi simultan digunakan secara langsung untuk mendapatkan beberapa sifat fisis yang diinginkan. Seperti impedansi P impedansi S, densitas, Poisson' ratio, dan $V p / V s$.

Inversi simultan memiliki beberapa kelebihan sebagai berikut:

- Menghasilkan nilai Poisson's ratio yang memiliki resolusi sebaik hasil dari inversi terpisah (elastic inversion)

- Dapat mengestimasi densitas dari data seismik, digunakan sebagai data tambahan untuk memprediksi litologi dan fluida

- Prediksi secara akurat delta impedansi akustik dan delta Poisson's ratio yang dapat digunakan untuk menghitung perubahan tekanan dan saturasi.

\subsection{Lambda-Mu-Rho}

Lambda-Rho dan Mu-Rho merupakan parameter fisika batuan yang erat kaitannya dengan inkompresibilitas dan rigiditas. Rigiditas atau modulus geser didefinisikan sebagai resistansi batuan terhadap sebuah ketegangan yang mengakibatkan perubahan bentuk tanpa merubah volume total dari batuan tersebut. Rigiditas sensitif terhadap matriks batuan. Semakin rapat matriksnya makan akan semakin sulit pula mengalami slide over satu sama lain, dan benda tersebut dikatakan memiliki rigiditas yang tinggi. Sedangkan inkompresabilitas didefinisikan sebagai besarnya perubahan volume batuan apabila dikenai sebuah tekanan. Parameter inkompresabiltas biasanya dipakai sebagai indikator fluida pengisi pori batuan (Avseth dkk., 2010)

\section{METODE PENELITIAN}

Untuk melakukan karakterisasi reservoir, diperlukan penentuan parameter yang akan diinversi dan dapat menjelaskan sifat batuan di bawah permukaan. Analisis cross plot dilakukan untuk melihat hubungan antara parameterparameter fisis batuan sesuai dengan tujuan penelitian. Tujuan penelitian ini memetakan persebaran reservoir dan menentukan batas sebaran hidrokarbon yang ada pada zona target. Parameter yang akan di analisis adalah lambdarho, mu-rho, shear impedance, acoustic impedance, $V p / V s_{2}$ dan densitas.

Pada tahapan AVO well modeling, diperlukan membuat sintetik seismik dari log yang kemudian dilakukan analisis sintetik respon AVO. Di dalam tahapan membuat sintetik seismik dari log, memakai persamaan Zoeppritz, dengan number of angles 10, minimum offset 0 , dan maximum offset 45 .

Tahapan selanjutnya adalah melakukan analisis synthetic AVO response dengan masukan volume L-30 sintetis dalam bentuk angle gather. Masukan log akan digunakan untuk membuat model awal. Penyiapan data seismik pada diagram alir mencakup dari 3D pre-stack sampai partial gather. Angle gather digunakan untuk dasar penentuan rentang sudut dalam pembagian partial stack. Stack section digunakan untuk memudahkan dalam interpretasi dan well to seismic tie, dimana telah terdapat horizon dalam data awal. Untuk partial stack dibuat berdasarkan tahapan sebelumnya dengan mempertimbangkan rentang sudut dari angle gather dan $A V O$ analysis.

Model awal dari inversi simultan adalah masukan dari impedansi $\mathrm{P}$, impedansi $\mathrm{S}$ dan densitas yang telah tersedia di software Hampson-Russel. Penyebaran masing-masing nilai pada model dikontrol oleh data seismik dan data horizon. Untuk lebih jelasnya, dapat dilihat pada Gambar 2. 


\section{HASIL DAN PEMBAHASAN}

Hasil perbandingan cross plot nilai $\mathrm{Vp} / \mathrm{Vs}$ terhadap impedansi gelombang $\mathrm{P}$ dan nilai impedansi gelombang $\mathrm{P}$ dengan impedansi gelombang $\mathrm{S}$ antara sumur L-30 (Gambar 3) dan B-41 (Gambar 4) memperlihatkan bahwa terjadi anomali pada lapisan reservoir target dengan adanya perbedaan trendline pada sumur L-30 dan pada sumur B-41.

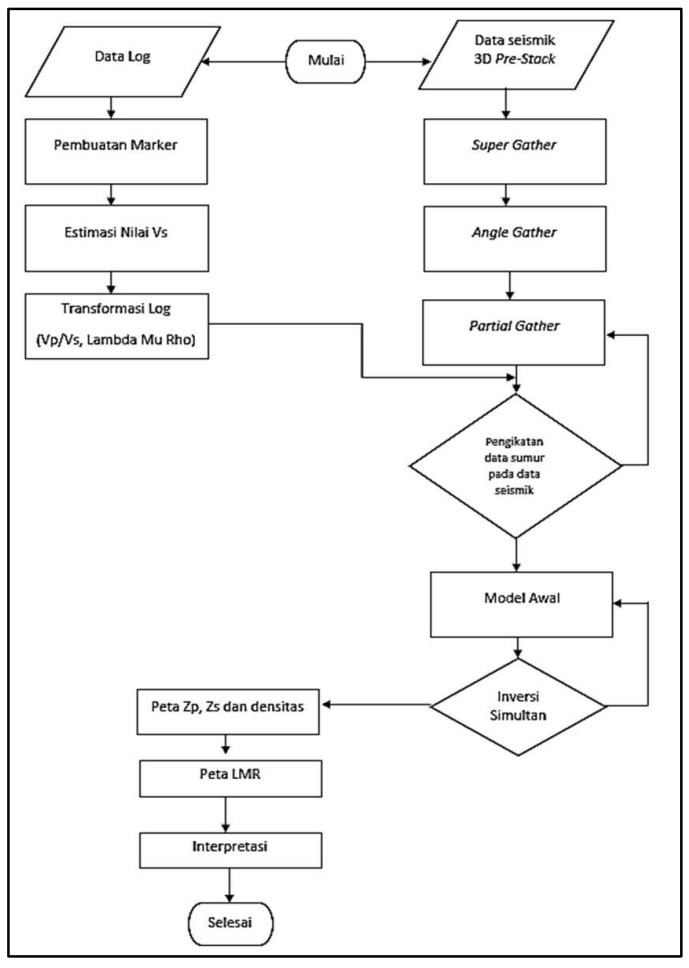

Gambar 2. Diagram alir penelitian.

Walaupun reservoir batupasir masih ditemukan di sumur B-41, ketebalan litologi tersebut tidak setebal lapisan reservoir yang berada di sumur L-30. Sementara itu, dari nilai log gamma ray dapat dilihat bahwa kualitas reservoir yang berada di sumur B-41 banyak dipengaruhi oleh perselingan batu-lempung yang bisa dilihat di Gambar 5.

Setelah dilakukan inversi simultan, maka dihasilkan 3 hasil inversi yaitu inversi $\mathrm{Zp}$, inversi $V p / V s$ dan inversi densitas yang dapat dilihat di Gambar 6. Hasil inversi simultan yang diperoleh dalam penelitian ini sebanyak 30 realisasi. Jumlah realisasi dipilih berdasarkan besarnya data, durasi proses dan kemampuan perangkat yang digunakan. Semakin banyak jumlah realisasi tentunya akan mempengaruhi penghitungan statistiknya, misal mereduksi ketidakpastian dengan lebih baik (Ma, 2019). Hasil inversi baik $\mathrm{Mu}$-Rho maupun Lamda-Rho memperlihatkan bahwa hasil inversi sudah cukup baik yang ditunjukkan oleh kesesuaian nilai (warna dan grafik) antara parameter sumur dan hasil inversi.

Hasil inversi pada zona target ditunjukkan dengan nilai impedansi $\mathrm{P}$, densitas dan $V p / V s$ yang relatif lebih rendah dibanding daerah lainnya. Hal ini juga sesuai dengan analisis penelitian lain yang menunjukkan pada daerah yang mengandung hidrokarbon memiliki nilai impedansi $\mathrm{P}$, densitas dan $V p / V s$ yang rendah seperti yang dilakukan oleh Hamada (2004).

Hasil sayatan inversi Zp, densitas dan Vp/Vs pada zona target diperlihatkan pada Gambar 7 . Dari gambar tersebut dapat dilihat nilai $\mathrm{Vp} / \mathrm{Vs}$ pada sumur B-41 bernilai tinggi yang ditandai dengan warna ungu. Analisis berikutnya menggunakan cross plot dari sumur B-41 untuk memperlihatkan mengapa B-41 merupakan $d r y$ well karena menurut inversi AI, nilai AI pada sumur B-41 relatif lebih tinggi dibanding L-30, yang menunjukkan nilai densitas pada sumur B-41 lebih tinggi daripada sumur L-30. Hal ini menunjukkan bahwa bahwa pada lapisan batuan reservoir B-41 memiliki pengaruh shally yang besar sehingga mempengaruhi kualitas reservoir.

Dari cross plot Gambar 8 dan Gambar 9, terlihat hubungan antara $\mathrm{Mu}$-Rho dengan impedansi P dan nilai $\mathrm{Mu}$-Rho dengan LambdaRho. Nilai $\mathrm{Mu}-\mathrm{Rho}$ rendah mengindikasikan bahwa reservoir mempunyai nilai rigiditas rendah sehingga diasumsikan kualitas reservoir batupasir pada sumur B-41 tidak sebaik reservoir pada sumur L-30 dikarenakan pengaruh kehadiran batulempung dan perselingan batulempung pada lapisan batupasir. Sedangkan dari Gambar 9 dapat 
dilihat bahwa nilai cut-off tidak bisa dengan jelas memisahkan zona reservoir yang terisi oleh gas dengan batulempung yang menjadi penyisip pada batuan reservoir sehingga dapat diinterpretasikan bahwa kualitas reservoir pada sumur B-41 relatif lebih buruk dari sumur L-30.

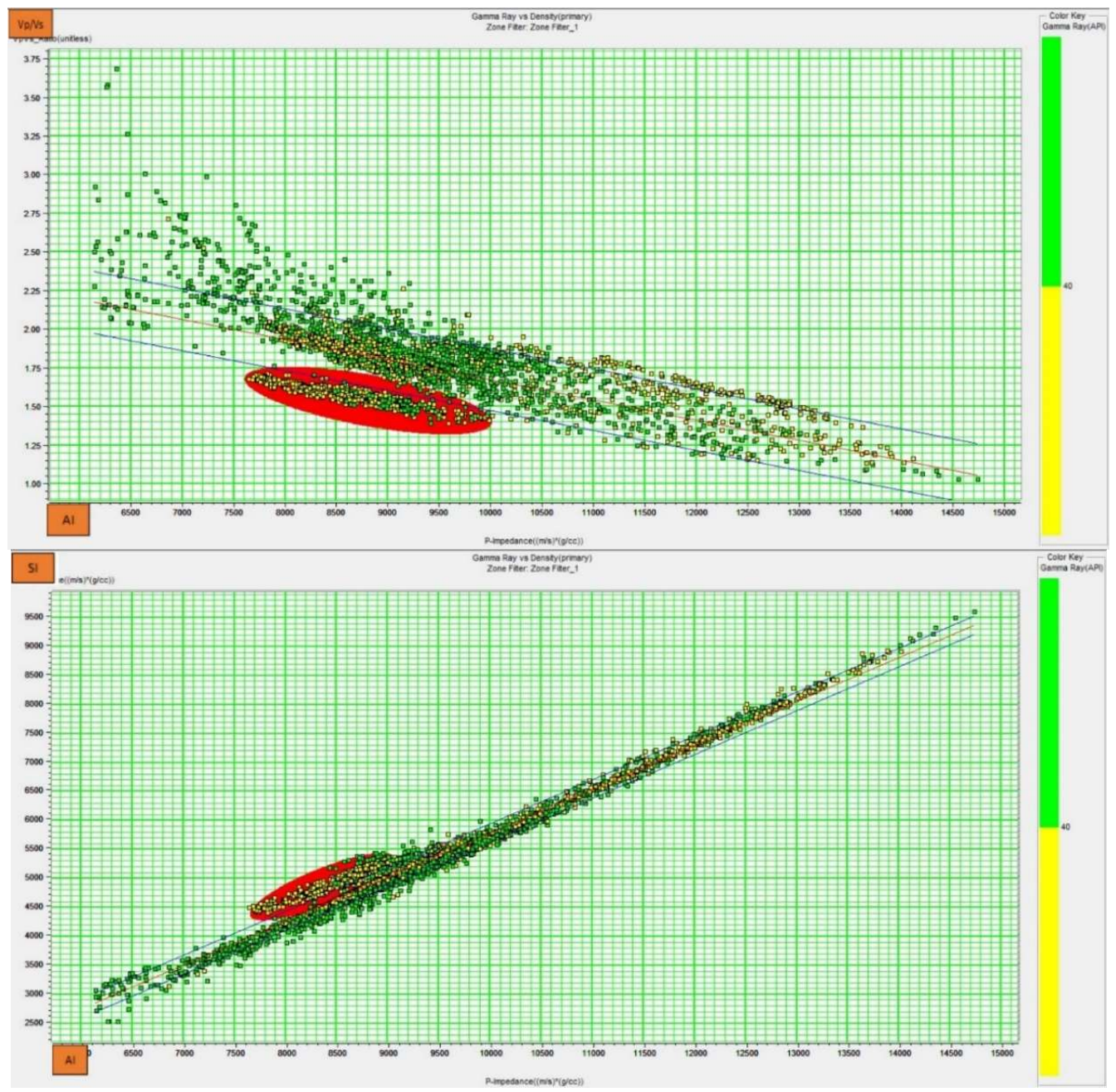

Gambar 3. Cross plot nilai log antara $V p / V s$ dengan Impedansi P dan Impedansi P dengan Impedansi S Sumur L-30. 


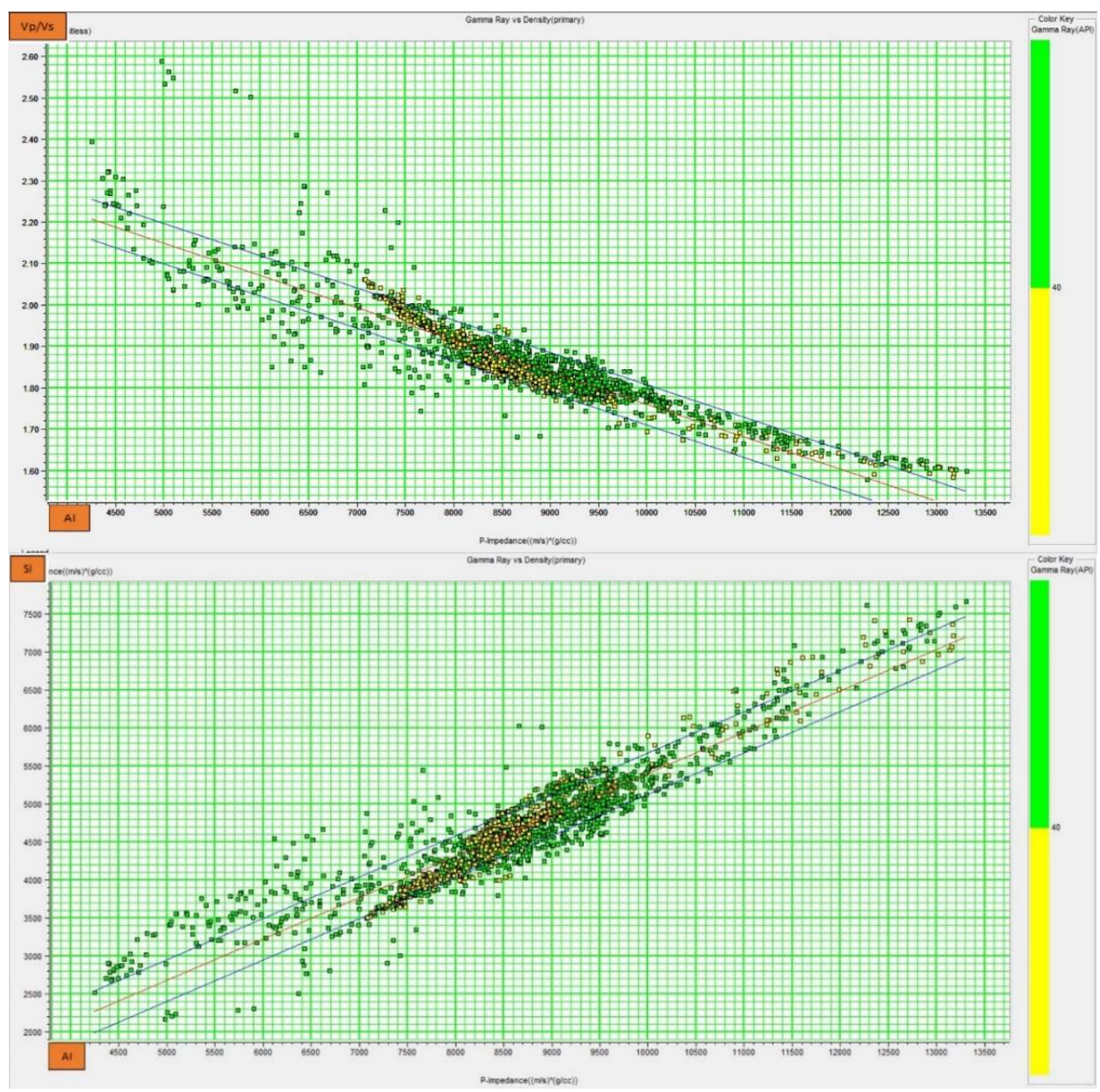

Gambar 4. Cross plot nilai log antara Vp/Vs dengan Impedansi P dan Impedansi P dengan Impedansi S Sumur B-41.

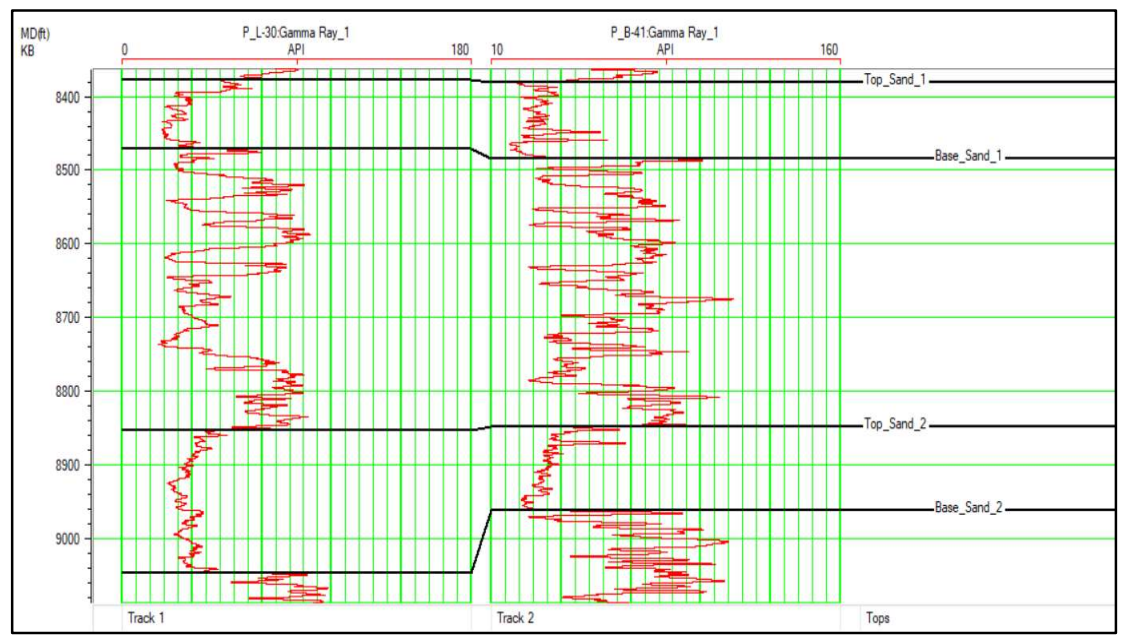

Gambar 5. Korelasi sumur L-30 dan B-41 berdasarkan nilai Gamma Ray. 


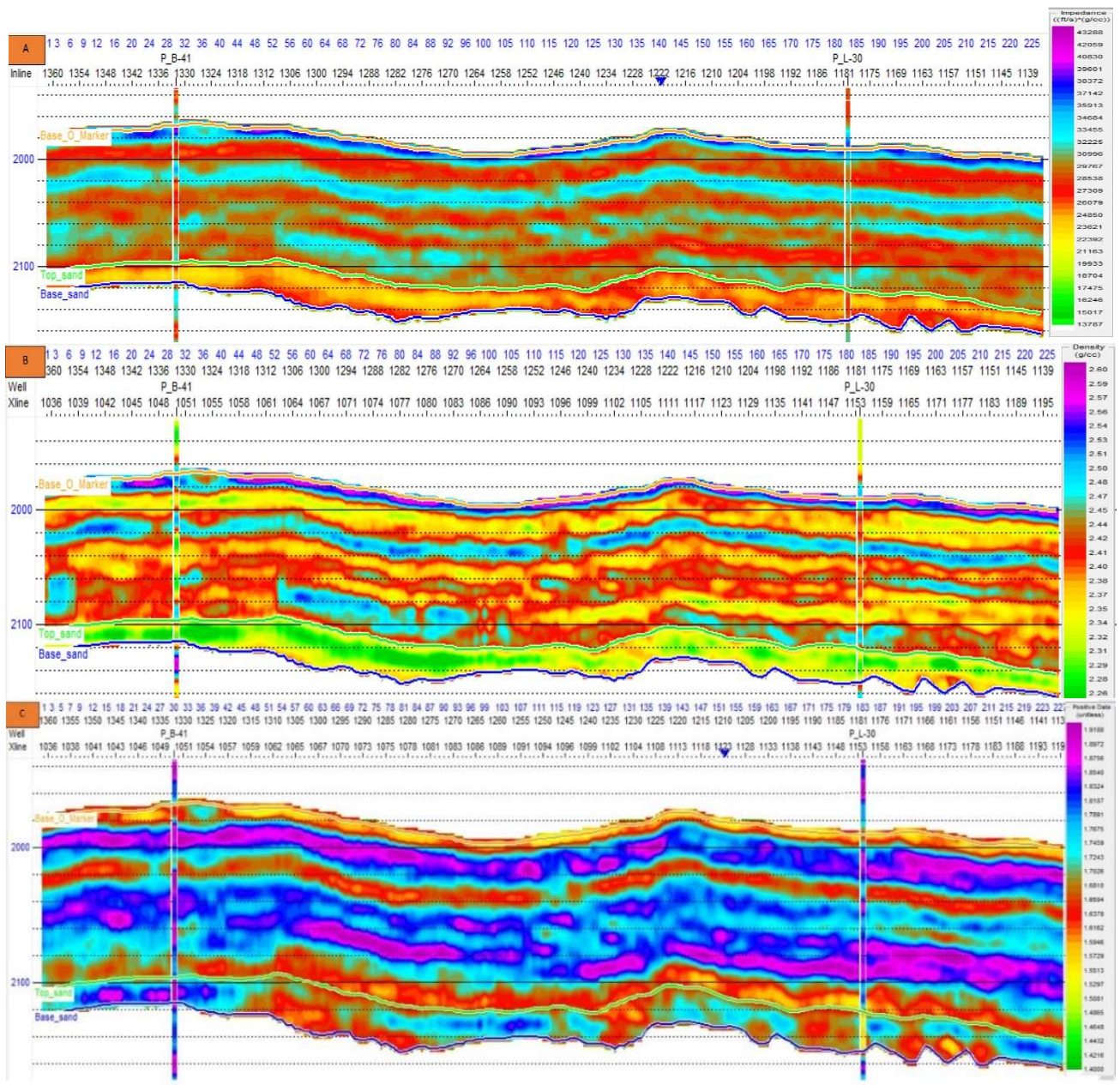

Gambar 6. Hasil inversi simultan (A,B,C secara berurutan Zp, Densitas dan VP/Vs).

Tujuan lain penelitian ini adalah menentukan batas persebaran reservoir batupasir serta hidrakarbon yang pada kasus ini adalah gas, maka dari hasil inversi simultan yang telah dilakukan akan ditransformasikan menjadi nilai Lambda-Mu-Rho (Close dkk., 2015). Secara teori, nilai Mu-Rho untuk batupasir akan bernilai diatas $20 \mathrm{Gpa}^{\star} \mathrm{g} / \mathrm{cc}$ dan Lambda-Rho untuk batuan mengandung hidrokarbon pada porinya akan bernilai rendah. Dari nilai cut off analisis data sumur diketahui bahwa range nilai $M u$-Rho zona target adalah 22-28 Gpa ${ }^{\star}$ / $/ \mathrm{cc}$ dan nilai LambdaRho adalah 17-22 $\mathrm{Gpa}^{*} \mathrm{~g} / \mathrm{cc}$ yang dapat dilihat pada Gambar 10. Nilai tersebut akan dijadikan acuan untuk menentukan persebaran batuan reservoir dan hidrokarbon pada zona target.

Dari Gambar 11 dapat dilihat bahwa secara teoritis hasil inversi telah cukup baik karena zona target mempunyai nilai $\mathrm{Mu}$-Rho diatas 20 $\mathrm{Gpa}^{*} \mathrm{~g} / \mathrm{cc}$ dan mempunyai nilai Lambda-Rho yang rendah dan telah sesuai dengan nilai log sumur. 


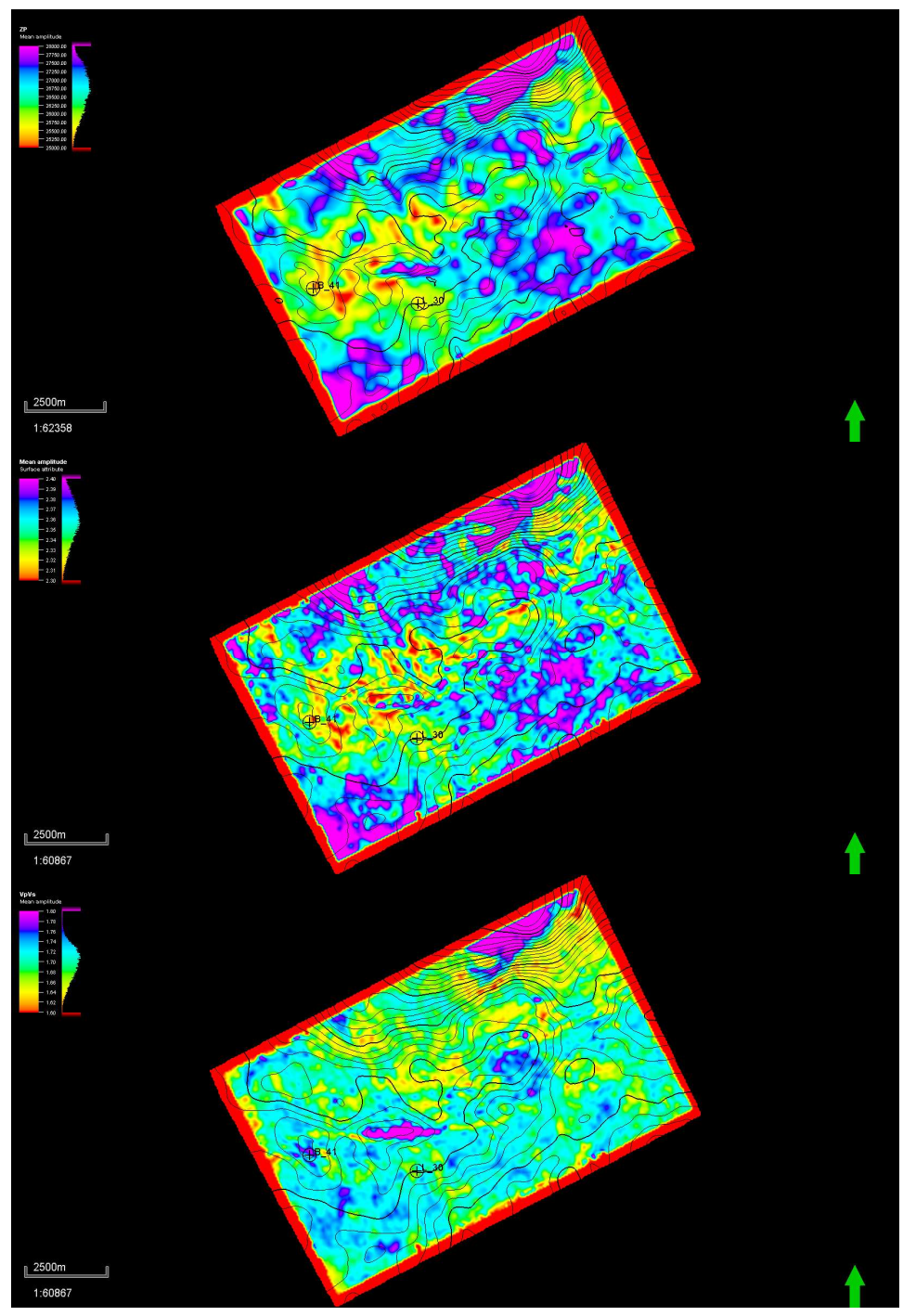

Gambar 7. Hasil sayatan struktur waktu zona target inversi simultan (A,B,C secara berurutan $Z p$, Densitas dan $V p / V s)$ 


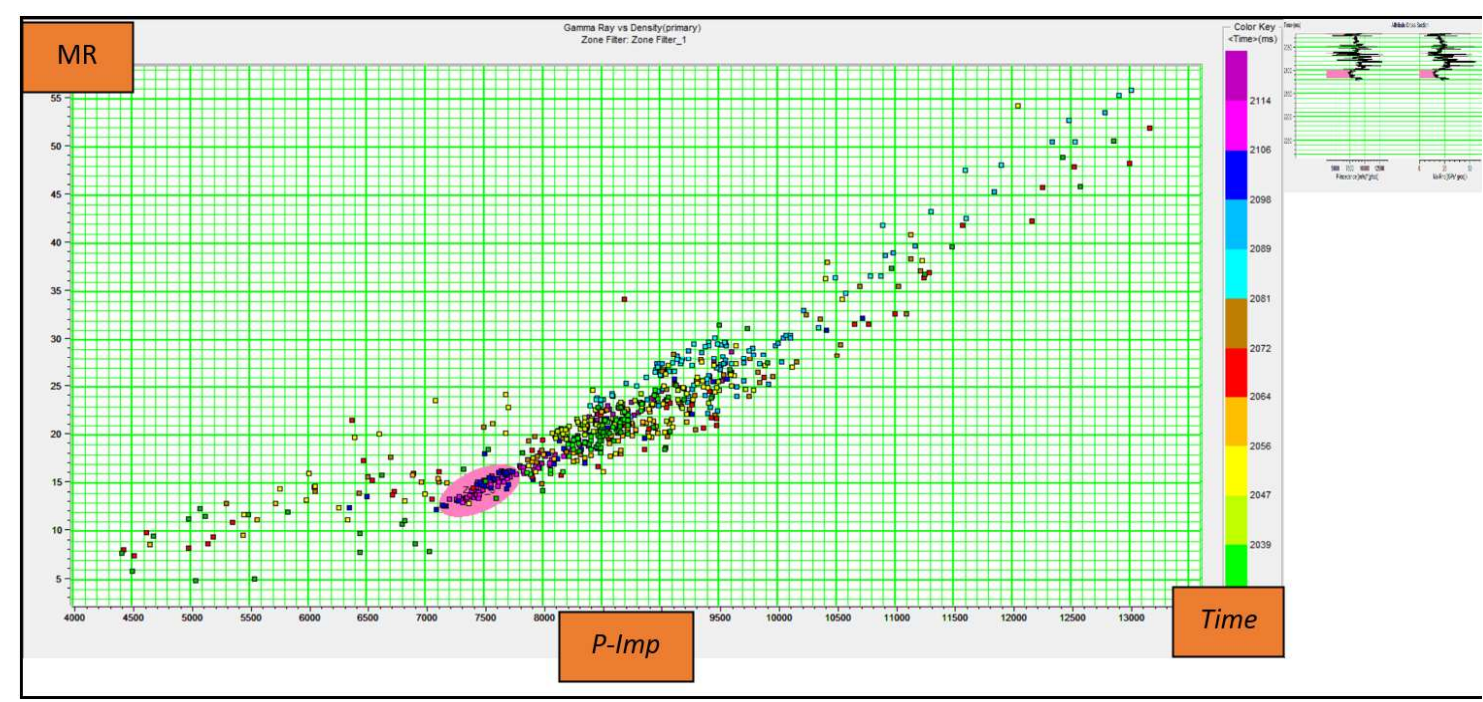

Gambar 8. Cross plot antara Mu-Rho dan P-Impedance pada sumur B-41.

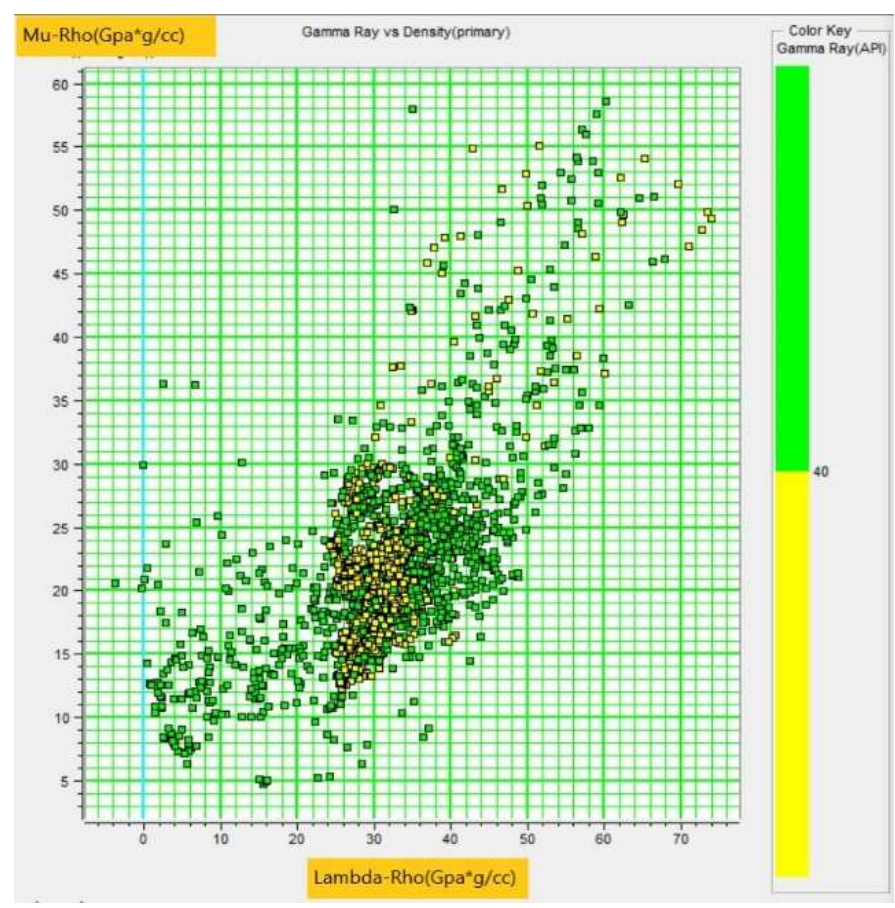

Gambar 9. Cross plot antara Mu-Rho dan Lambda-Rho pada sumur B-41. 


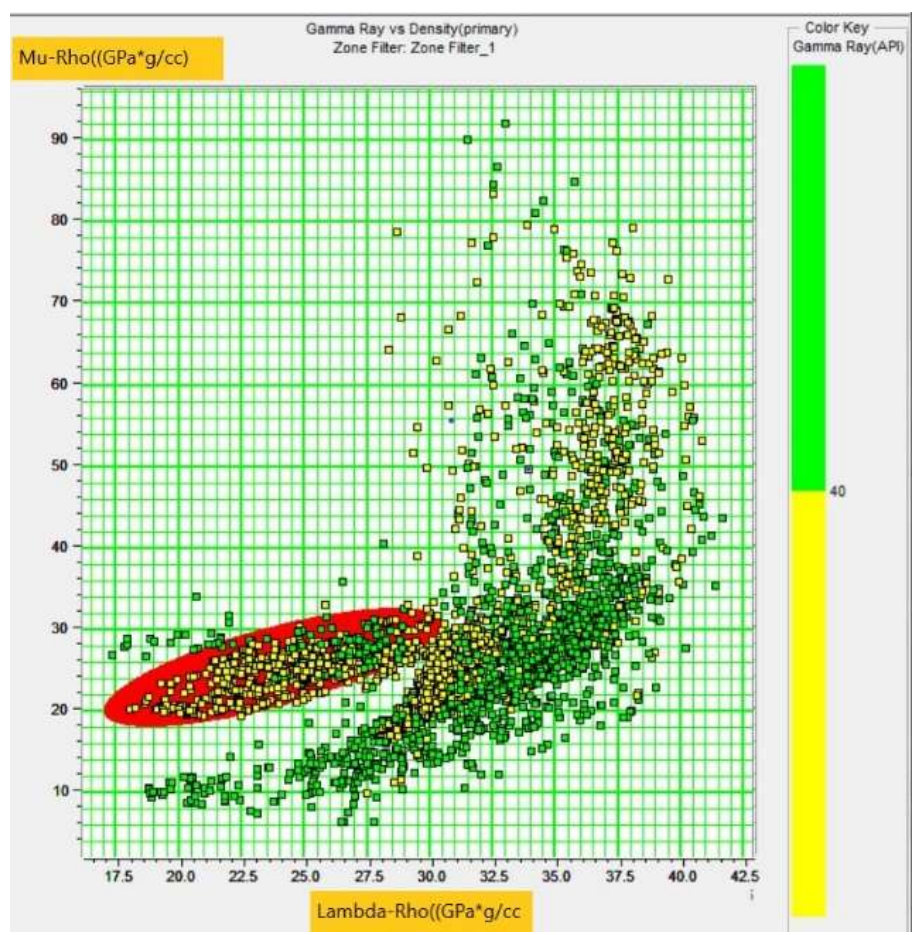

Gambar 10. Cross plot antara Mu-Rho dan Lambda-Rho pada sumur L-30.
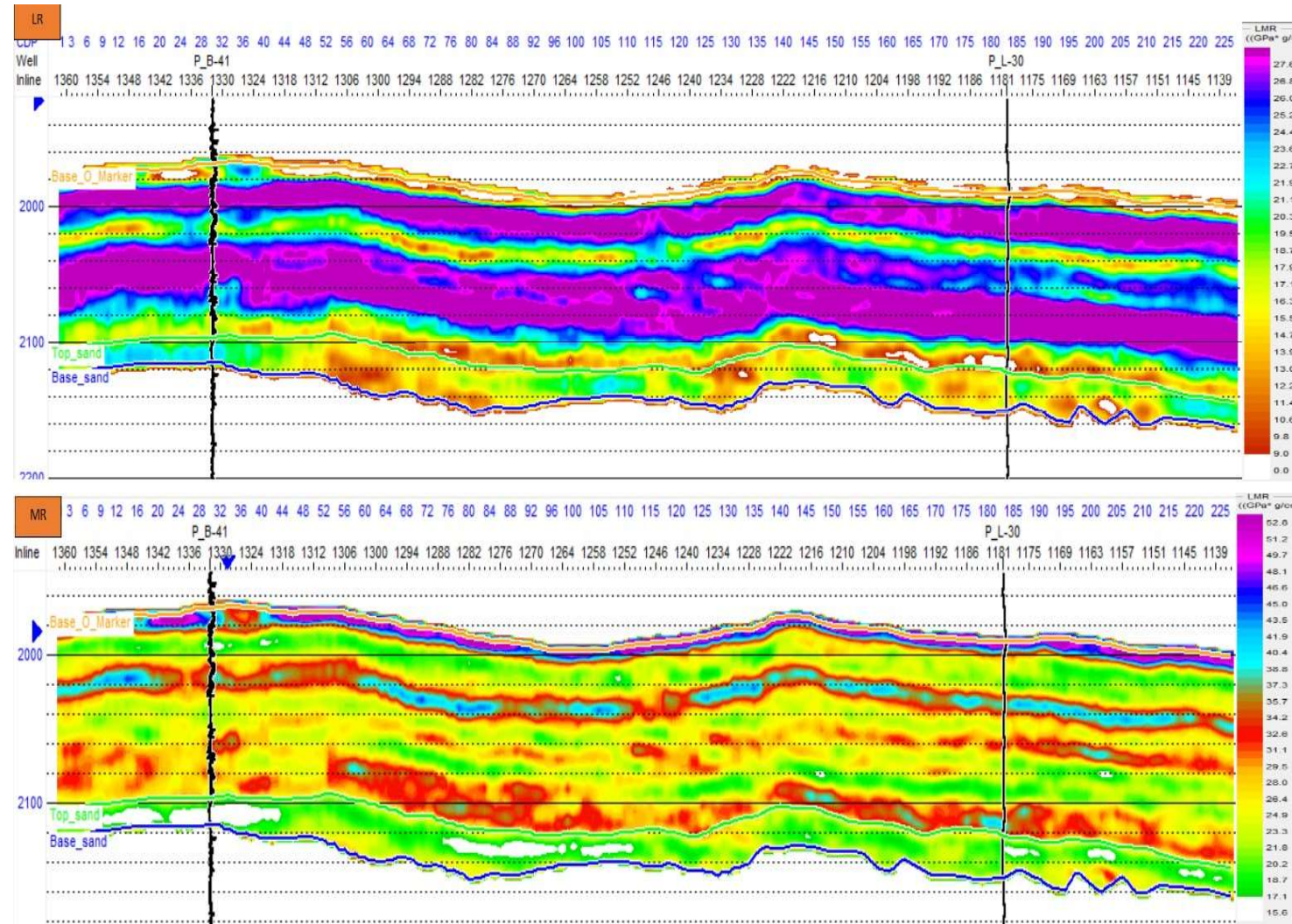

Gambar 11. Hasil transformasi LMR dari inversi simultan. 


\section{KESIMPULAN}

Dari keseluruhan proses penelitian dapat diambil kesimpulan, yaitu :

1. Hasil transformasi LMR dari inversi simultan telah mampu menyediakan salah satu alat untuk mengetahui penyebaran batupasir sebagai reservoir dan keberadaan hidrokarbon gas.

2. Sumur B-41 merupakan dry hole karena memiliki nilai $\mathrm{Mu}$-Rho yang rendah karena perselingan reservoir dengan batulempung sehingga diasumsikan mempunyai kualitas yang lebih buruk jika dibandingkan dengan sumur L-30.

3. Dari hasil inversi simultan, dapat diketahui zona-zona yang mempunyai nilai $\mathrm{Vp} / \mathrm{Vs}$ yang rendah yang berpotensi dijadikan sebagai salah satu indikasi adanya hidrokarbon gas yaitu berada pada area timur laut dari sumur L-30.

\section{UCAPAN TERIMA KASIH}

Penulis mengucapkan terima kasih kepada Program Studi Teknik Geofisika, Fakultas Teknik Pertambangan dan Perminyakan Institut Teknologi Bandung yang telah memfasilitasi penulis dalam penelitian ini.

\section{DAFTAR PUSTAKA}

Avseth, P., Mukerji, T., \& Mavko, G. (2010). Quantitative Seismic Interpretation: Applying Rock Physics Tools to Reduce Interpretation Risk. Cambridge University Press.

Campbell, T. (2014). Seismic Stratigraphy and Attribute Analysis of The Mesozoic and. March.

Castagna, J. P., \& Swan, H. W. (1997). Principles of AVO Crossplotting. The Leading Edge, 16(4), 337-344.

Close, D., Taylor, R., \& Nixon, S. (2015). Rock
Physics and Quantitative Interpretation Using Lambda-Mu-Rho in The Shipwreck Trough, Otway Basin. ASEG Extended Abstracts, 2015(1), 1-4.

https://doi.org/10.1071/aseg2015ab074

Ekine, A. S. (2013). Delineation of Hydrocarbon Bearing Reservoirs from Surface Seismic and Well Log Data (Nembe Creek) In Niger Delta Oil Field. IOSR Journal of Applied Physics, 4(3), 2630. https://doi.org/10.9790/4861-0432630

Hamada, G. M. (2004). Reservoir Fluids Identification Using $\mathrm{Vp} / \mathrm{Vs}$ Ratio? Oil \& Gas Science and Technology, 59(6), 649-654. https://doi.org/10.2516/ogst:2004046

Hampson, D. P., Russell, B. H., \& Bankhead, B. (2005). Simultaneous Inversion of Pre-Stack Seismic Data. In SEG Technical Program Expanded Abstracts 2005 (pp. 1633-1637). Society of Exploration Geophysicists.

Liu, H. (2017). Principles and Applications of Well Logging. In Principles and Applications of Well Logging. $\quad$ https://doi.org/10.1007/978-3-66254977-3

Ma, Y. Z. (2019). Quantitative Geosciences: Data Analytics, Geostatistics, Reservoir Characterization and Modeling. In Quantitative Geosciences: Data Analytics, Geostatistics, Reservoir Characterization and Modeling. https://doi.org/10.1007/978-3-030-17860-4

Mavko, G., Mukerji, T., \& Dvorkin, J. (1998). The Rock Physics Handbook. Cambridge University Press.

Sukmono, S. (2007). Post and Pre Stack Seismic Inversion for Hydrocarbon Reservoir Characterization. Laboratorium Geofisika Reservoir, Program Studi Teknik Geofisika, Bandung.

Veire, H. H., \& Landro, M. (2006). Simultaneous Inversion of PP and PS Seismic Data. Geophysics, 71(3). https://doi.org/10.1190/1.2194533 